\title{
PERAN OTORITAS JASA KEUANGAN DALAM MENGAWASI RESIKO PEMBIAYAAN DALAM INVESTASI "BODONG"
}

\author{
Abd. Kadir Arno \\ Institut Agama Islam Negeri (IAIN) Palopo \\ Email : abdulkadir.arno@iainpalopo.ac.id \\ A Ziaul Assad \\ Institut Agama Islam Negeri (IAIN) Palopo \\ Email : aulassaad@gmail.com
}

\begin{abstract}
This article gives an overview of the role of financial services authorities in monitoring the risk of financing from investment that occurs in the community, the data used in this article are primary data in the form of laws and books relating to financial services authorities and financial and material risks secondary in the form of other reference materials that support the writing of this article. This article uses in-depth analysis techniques, which are to thoroughly examine and analyze the context discussed in this article. The conclusion of this article is that in every investment activity carried out in the community, it will have potential risks in the future, especially when there is a fraudulent investment in the community, therefore to overcome the existence of financial services authorities have the following roles: how to disseminate and inform the public about the characteristics of fundraising and financing, through seminars, and the Group Focus Discussion by involving academics as presenters 2) Facilitating dispute resolution between parties to disputes related to financing carried out by communities in a fictitious investment 3) Making regulations (regulation) as a form of protection so that there are no fraudulent investment activities in the community and 4) Making Investment Alert Task Force (Satgas) in each province in the archipelago.
\end{abstract}

Keyword: Illegal Investment, Financing Risk, Financial Services Authority

\begin{abstract}
Abstrak
Artikel ini memberikan gambaran peran otoritas jasa keuangan dalam rangka mengawasi resiko pembiayaan dari investasi bodng yang terjadi ditengah masyarakat, data yang digunakan dalam artikel ini yakni data primer dalam bentuk undang-undang dan buku-buku yang berkaitan dengan otoritas jasa keuangan dan resiko keuangan dan bahan sekunder dalam bentuk bahan referensi lain yang mendukung. Artikel ini menggunakan teknik in-depth analysis yaitu mengkaji dan menganalisis secara menyeluruh dari konteks yang dibahas. Kesimpulan dari artikel ini bahwa pada setiap kegiatan investasi yang dilakukan ditengah masyakat pasti akan memiliki potensi resiko dikemudian hari, utama ketika terjadi investasi bodong di tengah masyarakat, oleh karena itu untuk menanggulangi adanya tersebut otoritas jasa keuangan mempunyai peran sebagai berikut: 1) melakukan sosialisi dengan cara menyebarkan dan menginformasikan kepada masyarakat tentang karakteristik penghimpunan dana dan pembiayaan,
\end{abstract}


melalui seminar-seminar, dan Focus Discusion Grup dengan melibatkan para akademisi sebagai pemateri 2) Memfasilitasi penyelesaian sengketa antara pihak yang bersengketa terkait pembiayaan yang dilakukan oleh masyarakat yang dalam investasi fiktif 3) Membuat peraturan-peraturan (regulasi) sebagai bentuk proteksi sehingga tidak terjadi kegiatan investasi bodong di tengah masyarakat dan 4) Membuat Satuan Tugas (Satgas) Waspada Investasi di setiap propinsi di nusantara.

Kata Kunci: Investasi Bodong, Resiko Pembiayaan, Otoritas Jasa Keuangan

\section{PENDAHULUAN}

Salah satu unsur yang terkait dengan kondisi perekonomian nasional di suatu Negara adalah sistem keuangan dan aktivitas industri jasa keuangan lainnya. Masalah ini berasal dari dampak globalisasi dan kemajuan teknologi yang telah menyebabkan kompleksitas sistem keuangan. Pertumbuhan ekonomi yang pesat tidak lepas dari pengembangan sistem keuangan yang semakin canggih.

Secara global, pentingnya stabilitas sistem keuangan dalam perekonomian ditentukan oleh empat hal, yaitu 1) pertumbuhan sektor keuangan yang lebih besar daripada sektor riil, 2) integrasi global dan regional dari sistem keuangan, 3) kompleksitas sistem keuangan dan perubahan dalam sistem keuangan dan 4) komposisi proses sistem keuangan yang disesuaikan dengan kebutuhan kelompok aset non-moneter menjadi lebih penting. (Houben, 2004).

Otoritas Jasa Keuangan (OJK) mengeluarkan laporan pada surat kabar harian Kompas pada 3 Februari 2017, yang menunjukkan bahwa kinerja pertumbuhan kredit perbankan nasional sepanjang 2016 tidak terlalu menggembirakan. Dari Januari hingga Desember 2016, pertumbuhan kredit bank tercatat 7,87 persen. Berkenaan dengan Non Performing Loan (NPL) tahun ini, mencapai tingkat 2,93\%. Jika dibandingkan pada bulan sebelumnya, November 2016 NPL bank tembus pada angka 3,1\%. Sementara itu, dibandingkan dengan akhir 2015, masih relatif stabil di 2,4\% (Diah Setiawan, 2016).

Ditahun yang sama harian tempo memuat berita tertangal 27 September 2016 juga memuat laporan OJK yang mencatat bahwa Non Performing Finance (NPF) perbankan syariah turun dari 4,89 persen pada Juli 2015 menjadi 4,7 persen pada Juli 2016, melihat hal tersebut maka dapat dikatakan NPF perbankan syariah masih lebih tinggi dibanding dengan rasio kredit bermasalah (Non Performing Loan) perbankan konvensional.(Florentin, 2016).

Mengingat hal ini dapat dikatakan bahwa semua kegiatan bisnis selalu memiliki resiko dan potensi pengembalian. Demikian juga, lembaga keuangan bank konvensional dan bank syariah tentu saja akan dihadapkan dengan peluang untuk resiko dan pengembalian. Muhammad (2002) menyatakan bahwa jika dicermati lebih mendalam bank syariah merupakan bank yang sarat akan resiko, sebab kegiatan dan aktivitas yang dilakukan terkait dengan produk perbankan banyak mengandung banyak resiko, dimulai dengan resiko asimetri informasi, moral hazard maupun resiko sistemik. Itu sebabnya Solahudiin (2004) menyatakan bahwa bank syariah harus memiliki sistem pengawasan dan manajemen resiko yang kuat. Dengan sistem ini, bank syariah dapat mendeteksi 
dan mencegah mal administrasi dan kegagalan sistem dan prosedur di bank syariah.

Saat ini, lembaga yang paling diatur dan dikendalikan oleh pemerintah adalah lembaga dan isntitusi yang bergerak pada sistem keuangan. Pengawasan yang dilakukan oleh pemerintah melalui peraturan-peraturan (baca: regulasi) yang di keluarkan berkaitan dengan sistem keuangan. Regulasi ini umumnya digunakan untuk menghasilkan agregat produktivitas ekonomi dan untuk mencegah lembaga keuangan mengalami kegagalan (failure) di masa depan. (Joni Manurung 2009) menyatakan bahwa pengaturan ini muncul sebagai akibat dari masalah masalah agen yang disebabkan oleh adanya informasi asimetris.

Dalam menjalankan bisnisnya sebagai lembaga keuangan yang menjual kepercayaan dan layanan jasa, setiap bank berupaya menarik sebanyak mungkin pelanggan baru (baca: nasabah), untuk mengumpulkan dana dalam bentuk deposito dan juga untuk meningkatkan laba dengan memberikan kredit (Simorangkir 2004). Hal ini juga disampaikan oleh Firmansyah (2004), yang menyatakan bahwa kredit adalah pendapatan utama dalam membiayai kegiatan operasioanl bank di Indonesia.

Pada dasarnya pendapatan bank dari Kredit memiliki resiko yang cukup besar karena tidak semua pinjaman kepada masyarakat melaui kredit yang diberikan bebas dari resiko. Firmansyah (2014) mengungkapkan bahwa pada kenyataannya pinjaman yang disalurkan ke masyarakat tidak semuanya pinjaman yang tergolong sehat, tetapi di antaranya kredit yang berkualitas buruk atau bermasalah. Tingkat terjadinya kredit bermasalah disebut Non Performing Loans (NPL), sebuah fenomena yang sering terjadi di dunia perbankan, karena salah satu kegiatan perbankan yang paling penting berasal dari pinjaman. Jika kredit bermasalah tinggi, itu akan menjadi masalah serius yang mengganggu profitabilitas bank dan menyebabkan penghentian operasi bank.

Berkenaan dengan berbagai jenis resiko yang dihadapi oleh bank, Bank Indonesia dan Otoritas Jasa Keuangan telah menyusun berbagai peraturan. Peraturan Bank Indonesia (PBI) No. 13/23 / PBI / 2011 tentang penerapan manajemen resiko untuk Bank Umum Syariah (BUS) dan Unit Usaha Syariah (UUS). Serta Peraturan No. 16 / POJK.03 / 2014 tentang Otoritas Jasa Keuangan tentang Penilaian Kualitas Aset Bank Umum Syariah (BUS) dan Unit Usaha Syariah (UUS).

Peraturan tersebut berfungsi untuk mengatur perbankan syariah, tetapi juga sekaigus menjadi masalah tersendiri bagi manajemen bank. Adanya legalitas formal bank di atas memaksa bank untuk lebih berhati-hati dalam mengelola kebijakan. Namun, peraturan yang ada menunjukkan bahwa perubahan dalam perilaku manajemen bank telah menjadi lebih betrhati-hati (hyperprudent) dalam arah pembagian keuntungan. Akibatnya, bank-bank Islam kehilangan kreativitas mereka untuk berfungsi sebagai salah satu pendorong pertumbuhan ekonomi bagi masyarakat (ummat) dan lapangan kerja. Sebagaimana diungkapkan oleh Iskandar (2012) bahwa peraturan tersebut juga berdampak pada sikap "memutilasi" prinsip taāwun (bantuan) kepada bank syariah dalam penyediaan produk pembiayaan.

Secara umum, resiko pembiayaan, yang merupakan kredit bermasalah, tampaknya tidak berkembang secara tiba-tiba. Kredit macet timbul melalui proses. 
Banyak gejala yang terjadi jauh sebelum masalah pinjaman (baca: kredit bermasalah) itu sendiri muncul. Jika gejala-gejala ini dapat diidentifikasi dengan benar dan dapat ditangani dengan cepat, ada harapan bahwa kredit tersebut dapat diselamatkan. Sebaliknya, jika tidak terdeteksi dan dibiarkan, akan menyebabkan kerugian, terutama pada kreditor atau bank itu sendiri.

Artikel ini dimaksudkan untuk menggambarkan peran Otoritas Jasa Keuangan sebagai lembaga yang diakui oleh pemerintah yang tugasnya mengatur dan mengendalikan kegiatan jasa keuangan di sektor perbankan, dalam kaitannya meminimalkan resiko dalam pembiayaan.

\section{METODE PENELITIAN}

1 Data

Data yang digunakan dalam artikel ini adalah data primer dalam bentuk undang-undang dan buku-buku yang berkaitan dengan otoritas jasa keuangan dan resiko keuangan dan bahan sekunder dalam bentuk bahan referensi lain yang mendukung penulisan artikel ini.

2 Teknik analisis

Artikel ini menggunakan teknik in-depth analysis yaitu mengkaji dan menganalisis secara menyeluruh, karena metodologi kualitatif percaya bahwa sifat masalah berbeda dari sifat masalah lainnya. Tujuan dari metode ini bukan generalisasi tetapi pemahaman yang mendalam tentang suatu masalah.

\section{PEMBAHASAN}

\section{Otoritas Jasa Keuangan (OJK)}

Secara historis, gagasan untuk mendirikan lembaga khusus untuk melakukan pengawasan perbankan telah meningkat sejak dikeluarkannya UndangUndang Nomor 23 Tahun 1999 tentang Bank Indonesia. Undang-undang tersebut menjelaskan bahwa tugas mengawasi bank akan dilaksanakan oleh lembaga pengawas penyedia layanan keuangan independen dan ditetapkan oleh hukum. Dengan melihat ketentuan-ketentuan ini, jelas bahwa lembaga pengawas independen untuk jasa keuangan harus dibentuk dan menjadi dasar dari pembentukan lembaga independen yang mengawasi sektor keuangan.

Namun dalam prosesnya, hingga tahun 2010 gagasan untuk mendirikan lembaga pengawas ini, yang kemudian dikenal sebagai Otoritas Jasa Keuangan (OJK), masih belum terealisasi. Kondisi ini disebabkan dalam kurun waktu hampir satu dekade, Otoritas Jasa Keuangan (OJK) tidak bisa menjadi pengawas pengembangan sistem perbankan. Otoritas Jasa Keuangan (OJK) dianggap penting menjadi suatu lembaga pengembangan praktik dan pengawasan perbankan ketika terjadi kasus besar yang menyitaperhatian public yaitu kasus Bank Century, yang dalam kasus ini Bank Century yang melakukan penyimpangan tanpa ada rasa takut akan tindakan dan karena memang tidak ada lembaga tertentu yang menjadi pengawas pada saat itu.

Sehingga pada tahun 2011 pemerintah menerbitkan Undang-Undang Nomor 21 tahun 2011 tentang Otoritas Jasa Keuangan (OJK), yang dalam undang-undang ini menetapkan bahwa OJK adalah lembaga independen, tetapi undang-undang tersebut secara efektif mulai berlaku sejak 1 Januari 2013. Lembaga independen tersebut akan bertanggung jawab untuk mengatur dan 
mengawasi perbankan dan lembaga non-keuangan secara terintegrasi, yang secara sekaligus mengambil alih pengawasan bank dan lembaga non-keuangan, yang dilakukan oleh Bank Indonesia sebagai pengawas untuk Bank dan BapepamLK untuk lembaga keuangan non-bank.

Otoritas Jasa Keuangan, sebagai lembaga negara yang independen dan bebas dari campur tangan pihak lain yang memiliki fungsi mengatur sistem peraturan dan pengawasan yang terintegrasi pada semua kegiatan di sektor jasa keuangan di Indonesia, memainkan peran penting dalam penanganan kasus pada lembaga keuangan yang sedang berkembang saat ini di Indonesia seperti inveastiinevsatsi bodong (baca: Ilegal)

Dian Husna Fadlia dan Yunanto (2015) menyatakan bahwa peningkatan penipuan investasi fiktif disebabkan oleh kurangnya pengetahuan publik tentang sektor keuangan dan keinginan masyarakat untuk mendapatkan keuntungan yang sangat tinggi, meskipun didalamnya terdapat orang-orang yang berpendidikan juga menjadi korban dari penipuan investasi. Oleh karena itu, OJK sangat dibutuhkan untuk memberikan perlindungan hukum bagi investor dalam investasi fiktif. Dian Husna menambahkan bahwa perlindungan hukum bagi calon investor maupun investor yang dilakukan oleh OJK dengan langkah-langkah preventif dan represif. Tindakan prefentif yang dilakukan oleh OJK untuk mencegah orang terjebak dalam investasi fiktif. Sementara itu, tindakan represif oleh OJK dapat dilakukan dengan proses hukum ke perusahaan investasi fiktif oleh tim investasi hati-hati karena perlindungan hukum represif ditujukan untuk menyelesaikan sengketa

Otoritas Jasa Keuangan memilki fungsi sebagaimana yang tertuang dalam Pasal 5 UU OJK menyatakan bahwa OJK memiliki fungsi untuk mengatur sistem regulasi dan pengawasan yang terintegrasi pada semua kegiatan di sektor jasa keuangan, sehingga semua fungsi regulasi dan pengawasan sektor keuangan masih berada pada Bank Indonesia dan Bapepam-LK akan diintegrasikan ke dalam OJK. Oleh sebab itu Otoritas Jasa Keuangan memiliki fungsi-fungsi berikut:

a. Mengawasi aturan yang telah diterapkan dari Forum Stabilitas Keuangan;

b. Menjaga dan Memastikan stabilitas sistem keuangan;

c. Melakukan pengawasan kepada lembaga keuangan non-bank;

d. Pengawasan pada lembaga keuangan perbankan yang berada di luar kompetensi BI sebagai bank sentral dan dipegang oleh OJK.

\section{Resiko Pembiayaan}

Pembiayaan adalah suatu proses yang dimulai dengan analisis kelayakan pembiayaan hingga realisasinya. Setelah realisasi pembiayaan, bank harus mengawasi karena bank tidak mungkin ingin memiliki pembiayaan bermasalah walaupun dengan berbagai alasan selama dalam jangka waktu pembiayaan. Bank harus mampu menganalisis penyebab pembiayaan bermasalah sehingga mereka dapat melakukan upaya lebih lanjut dalam menjaga kualitas pembiayaan.

Pembiayaan bermasalah adalah pembiayaan yang menurut kualitasnya didasarkan pada resiko kemungkinan bahwa pelanggan pembiayaan memenuhi kewajiban untuk membayar pembiayaan. Kualitas suatu pembiayaan dapat dinilai berdasarkan kategori sebagai berikut: 
a. Lancar

Pembiayan dikategorikan lancar jika pembayaran angsuran dan pembayaran margin tepat waktu, tidak ada tunggakan, sesuai dengan persyaratan kontrak, selalu menyerahkan laporan keuangan yang teratur dan akurat, secara dokumentasi kontrak perjanjian piutang yang diterima lengkap.

b. Dalam Perhatian Khusus

Pembiayan dikategorikan dalam perhatian khusus jika terdapat tunggakan pembayaran angsuran pokok atau margin pengembalian lewat dari 90 hari serta pelanggaran dari kontrak perjanjian yang dilakukan bukan masalah yang prinsipil, Namun nasabah masih selalu mengirim laporan keuangan secara teratur dan akurat, secara dokumentasi kontrak perjanjian piutang yang diterima lengkap.

c. Kurang Lancar

Pembiayan dikategorikan kurang lancar jika ada tunggakan pembayaran pokok dan / atau margin yang telah lewat dari 90 hari menjadi 180 hari serta pelanggaran terhadap persyaratan dasar dari perjanjian dalam kontrak dan upaya dilakukan untuk menambah piutang dalam rangka untuk menyembunyikan kesulitan keuangan yang dihadapi, penyampaian laporan tahunan tidak teratur dan dipertanyakan, dokumentasi perjanjian tidak lengkap.

d.Diragukan

Pembiayan dikategorikan diragukan jika terjadi tunggakan pembayaran angsuran pokok dari pembiayaan telah melewati 180 hari kerja hingga dengan 270 hari kerja, terjadi pelanggaran yang prinsipil dari persyaratan pokok yang disepakati, tidak menyampaikan informasi keuangan tepat waktu, ketika menyampaikan informasi keuangan, informasi tersbut tidak dapat dipercaya.

e. Macet

Pembiayan dikategorikan macet apabila terjadi tunggakan pembayaran angsuran pokok atau margin melewati 270 hari kerja serta dokukomentasi dari perjanjian kontrak piutang agunan tidak ada

Dalam berbagai peraturan yang dikeluarkan oleh Bank Indonesia tidak terdapat definisi tentang Pembiayaan bermasalah. Demikian pula, istilah Non Performing Finance (NPF) untuk memfasilitasi pembiayaan dan istilah Non Performing Loan (NPL) untuk fasilitas kredit tidak ditemukan dalam peraturanperaturan tersebut, akan tetapi dalam setiap laporan dalam statistik Perbankan yang diterbitkan istilah Non-Performing Financing (NPF) dapat diartikan sebagai pembiayaan non lancar mulai dari kurang lancar hingga macet.

Pembiayaan bermasalah dapat dilihat dari segi produktivitas (Kinerja), yaitu berkenaan dengan kemampuan menghasilkan pendapatan bagi Bank, jika berkurang atau dikurangi dan mungkin tidak ada lagi, tentu mengurangi pendapatan dan meningkatkan biaya pencadangan, yaitu penyisihan penghapusan aktiva produktif (PPAP) dan dalam skala makro ekonomii dapat mengurangi kontribusi untuk pembangunan dan pertumbuhan ekonomi.

\section{Investasi "Bodong" (Fiktif)}

Penanaman modal yang biasa disebut dengan investasi, sekarang menjadi istilah yang akrab bagi publik. Namun saat ini Praktik Investasi Ilegal, yang sering disebut sebagai investasi bodong juga berkembang di tengah masyarakat. Masyarakat diiming-imingi (baca: dijanjikan) untuk mendapatkan keuntungan 
(bunga) tetap setiap bulan meskipun perusahaan dalam keadaan mengalami kerugian. Oleh karena bentuk investasi yang tidak jelas dan tidak masuk akal, dan spekulatif, maka pelaku berusaha menghindari aturan perbankan dalam mengumpulkan dana dari masyarakat dalam bentuk deposito. (Arsil, 2013:4).

Investasi ilegal menggunakan skema Ponzi atau skema money game, yaitu memutar dana dari masyarakat dengan membayar bonus kepada konsumen lama dari sumber dana pembiayaan dari konsumen baru. Tidak ada terdapat kegiatan bisnis yang nyata untuk mengelola dalam menopang pembayaran keuntungan kepada masyarakat, yang pada akhirnya akibat dari kegiatan tersebut dapat dapat diprediksi , masyarakat akan kehilangan dananya dalam waktu singkat karena dana tersebut ditransfer ke pihak lain yang berpartisipasi terlebih dahulu. Selain itu, untuk menarik masyarakat akan kegiatan investasi yang dilakukan pelaku menggunakan fasilitas publik untuk memudahkan orang mengikuti praktik ini. Penggalangan dana publik yang dilakukan dijanjikan mendapatakan keuntungan yang sangat menggoda atau dengan bunga yang melebihi batas wajar (Arsil, 2013: $1)$.

Dalam suatu investasi terdapat potensi penyalahgunaan/ penyelewenangan (Moral Hazard) dari pelaku ekonomi yang tentunya akan memiliki efek negatif terhadap perekonomian, oleh sebab itu sangat penting dilakukan suatu pengawasan. Moral hazard terjadi akibat dari suatu informasi yang asimetris. Informasi asimetris adalah situasi di mana informasi tidak tersebar secara merata di antara para pelaku ekonomi. Akibat dari informasi yang asimetris yaitu terjadinya moral hazard dan adverse selection (Hermansyah 2013). Lebih lanjut Hermansyah menjelaskan bahwa praktik moral hazard di sektor keuangan tidak hanya dilakukan oleh lembaga keuangan, tetapi juga oleh pelanggan/rumah tangga. Resiko moral timbul karena lemahnya sistem pengawasan lembaga keuangan yang disebabkan oleh sistem arsitektur pengawasan keuangan yang lemah di Indonesia, sehingga a) Tidak terjadi pertukaran arus informasi (pertukaran data dan interfacing data) yang terjadi antara lembaga pengawas lembaga keuangan. b) Masih tingkat egois yang tinggi antara lembaga pengawas lembaga keuangan.

Analisis pembiayaan adalah suatu kegiatan berupa investigasi terhadap kelayakan proposal pembiayaan yang diajukan oleh nasabah. Atas dasar hasil analisis dapat diketahui apakah bisnis atau usaha dari nasabah tersebut layak (feasible) atau tidak. Layak (feasible) dapat diartikan bahwa perusahaan yang akan dibiayai diasumsikan menjadi sumber pengembalian atas pembiayaan yang akan dilakukan, jumlah pembiayaan sesuai dengan kebutuhan, baik dari sisi jumlah dan penggunaan serta struktur pembiayaan yang tepat, memastikan resiko dan keuntungan bagi bank maupun nasabah.

Bank dalam menyalurkan pembiayaan harus mengambil langkah-langkah yang tidak membahayakan bank itu sendiri dan kepentingan dari nasabah yang mempercayakan dana mereka untuk dikelola. Resiko pembiayaan dapat diminimalisir dengan cara melakukan analisis pembiayaan yang akan diberikan. Analisis pembiayaan adalah fase preventif yang paling penting dan diimplementasikan dengan secara profesional yang dapat bertindak sebagai filter 
pertama di sektor perbankan untuk meminimalisir bahaya dari pembiayaan bermasalah.

Dalam melaksanakan tugas-tugas pengaturan dan pengawasan, OJK memiliki wewenang:

1. Pengawasan dan Pengaturan Lembaga Keuangan Bank

a. Izin pendirian bank, pembukaan cabang bank, anggaran dasar, rencana kerja, kepemilikan, manajemen dan sumber daya manusia, merger, konsolidasi dan akuisisi bank, dan pencabutan izin usaha;

b. Kegiatan perbankan, termasuk sumber pembiayaan, penyediaan dana, dan aktivitas bank pada sektor jasa;

c. Pengaturan dan pengawasan kesehatan bank meliputi: likuiditas, profitabilitas, solvabilitas, kualitas aset, rasio solvabilitas minimum, batas kredit maksimum, rasio pinjaman terhadap deposito dan cadangan bank; laporan bank yang berkaitan dengan kesehatan dan kinerja bank; sistem informasi debitur; pengujian kredit; dan standar akuntansi bank;

d. Pengaturan dan pengawasan terkait dengan aspek kehati-hatian bank, termasuk: manajemen resiko; manajemen bank; prinsip mengetahui pelanggan; dan pencegahan pencucian uang, pendanaan terorisme dan kejahatan bank lainnya.

2. Peraturan lembaga jasa keuangan (bank dan non-bank) termasuk

a. Menetapkan regulasi-regulasi dan keputusan OJK;

b. Menetapkan regulasi-regulasi tentang pegawasan pada sektor jasa keuangan;

c. Menyusun dan menetapkan tentang pelaksanaan tugas OJK;

d. Menyusun dan menetapkan prosedur tata cara pengelola pada lembaga jasa keuangan;

e. menetapkan struktur organiasi serta ikut mengawasi lembaga keuangan

3. Pengawasan terhadap lembaga keuangan (bank dan non-bank), termasuk:

a. Menetapkan kebijakan pengawasan operasional lembaga keuangan;

b. Melakukan pengawasan pelaksanaan, perlindungan konsumen, tugas dari manager eksekutif dan tindakan lain terhadap lembaga keuangan;

c. Memberikan instruksi tertulis kepada lembaga keuangan dan / atau pihak tertentu;

d. Melakukan penunjukan dan Pengangkatan pengelola statuter;

e. Memberikan sanksi administratif terhadap pihak yang melanggar peraturan di sektor keuangan;

f. Memberi dan / atau menarik izin usaha, izin pribadi, surat pendaftaran terdaftar, persetujuan untuk melakukan kegiatan bisnis, ratifikasi, persetujuan atau penentuan pembubaran dan ketentuan lainnya.

Adapun peran Otoritas Jasa Keuangan (OJK) dalam menanggulangi adanya Resiko Pembiayaan dalam investasi bodong yang ada di masyarakat yaitu dengan cara:

1. Sosialisasi

Sosialisasi program dimaksudkan untuk menginformasikan dan mengingatkan masyarakat agar waspada dengan penghimpunan dana dan 
pembiayaan dari para pihak secara illegal. Untuk mencegah tindakan tersebut otoritas jasa keuangan:

a. Menyebarkan dan menginformasikan kepada masyarakat tentang karakteristik penghimpunan dana dan pembiayaan.

b. Mengadakan seminar, Focus Grup Discusion (FGD) atau dengan mengundang para pakar untuk membahas pengayaan materi sosialisasi, khususnya wawasan tentang investasi ilegal.

c. Otoritas Jasa Keuangan juga menyelenggarakan pertemuan media, yaitu dengan mengundang wartawan dari berbagai media untuk menginformasikan kepada publik tentang pemahaman investasi, khususnya yang berkaitan dengan pencegahan investasi bodong (ilegal) di masyarakat.

2. Penyelesaian Sengketa

Kegiatan transaksi di sektor keuangan mempunyai potensi menimbulkan resiko atau untuk perselisihan di masa depan, sehingga OJK perlu mengatur kewajiban para pelaku di sektor jasa keuangan untuk menyelesaikan pengaduan para konsumen, sebab pada saat menyelesaikan pengaduan para konsumen di lembaga keuangan, seringkali tidak terjadi kesepakatan antara kedua belah pihak di layanan pengaduan sektor keuangan. Jika konsumen tidak puas dengan penanganan pengaduan, konsumen dapat melanjutkan pengaduan ke pengadilan atau Lembaga Penyelesaian Sengketa Alternatif (LAPS) (Dian Husna Fadlia dan Yunanto, 2015: 213).

Peraturan tentang mekanisme penyelesaian sengketa di sektor keuangan juga merupakan mandat dari atau implementasi dari Pasal 29 (c) Undang-undang No 21 tahun 2011 tentang Otoritas Jasa Keuangan, di mana otoritas Jasa Keuangan di berikan tugas menangani pengaduan dari konsumen yang dirugikan oleh pelaku sektor jasa keuangan sesuai dengan hukum dan peraturan yag berlaku. 3. Membuat Regulasi

Dalam rangka untuk melakukan perlindungan hukum untuk konsumen maka otoritas jasa keuangan membuat regulasi. Regulasi yang dibuat akan menjadi pedoman bagi masyarakat untuk mengetahui industri keuangan mana yang berada di bawah pengawasan Otoritas Jasa Keuangan. Beberapa peraturan terkait dengan perlindungan Hukum terhadap korban investasi illegal yang dikeluarkan oleh otoritas jasa keuangan diantaranya:

a. Surat Edaran nomor 12 / SEOJK.07 / 2014 tentang penyerahan informasi dalam konteks pemasaran produk dan / atau jasa keuangan.

b. Surat Edaran Otoritas Jasa Keuangan (SE-OJK) Nomor 1 / POJK.07 / 2013 tanggal 6 Agustus 2013 tentang Perlindungan Konsumen di Sektor Jasa Keuangan, yang berlaku pada bulan Agustus tahun 2014. Surat edaran ini menetapkan bahwa penawaran POJK harus menggunakan data yang telah disetujui oleh konsumen atau masyarakat yang bersedia untuk dihubungi melalui pesan teks, telepon atau email.

c. Peraturan No 1 / POJK.07 / 2013 tentang Otoritas Jasa Keuangan tentang perlindungan konsumen di sektor keuangan, yang akan menjadi pedoman bagi lembaga jasa keuangan dan publik.

4. Membuat Satgas Waspada Investasi 
Dalam konteks optimalisasi, efisiensi dan respons cepat terhadap pengaduan dan/atau pelaporan dari publik tentang kegiatan penggalangan dana tanpa izin yang terjadi di daerah, OJK membetuk Tim Gugus Tugas Peringatan Investasi Regional dibentuk di 35 provinsi pada 2016. Gugus Tugas Peringatan Investasi melakukan kegiatan sosialisasi untuk peringatan waspada investasi illegal dan diskusi kelompok fokus untuk menangani laporan dugaan investasi bodong (illegal) yang terjadi di masyarakat.

\section{PENUTUP}

Pada setiap kegiatan investasi yang dilakukan ditengah masyakat pasti akan memiliki potensi resiko dikemudian hari, utama ketika terjadi investasi bodong di tengah masyarakat, oleh karena itu untuk menanggulangi adanya tersebut otoritas jasa keuangan mempunyai peran sebagai berikut:

1. Melakukan sosialisi dengan cara menyebarkan dan menginformasikan kepada masyarakat tentang karakteristik penghimpunan dana dan pembiayaan, melalui seminar-seminar, dan Focus Discusi Grup dengan melibatkan para akademisi sebagai pemateri.

2. Memfasilitasi penyelesaian sengketa antara pihak yang bersengketa terkait pembiayaan yang dilakukan oleh masyarakat yang dalam investasi fiktif

3. Membuat peraturan-peraturan (regulasi) sebagai bentuk proteksi sehingga tidak terjadi kegiatan investasi bodong di tengah masyarakat.

4. Membuat Satuan Tugas (Satgas) Waspada Investasi di setiap propinsi di nusantara.

\section{DAFTAR PUSTAKA}

Arsil. (2013). Menjerat Investasi Bodong dengan Tindak Pidana Perbankan. Jakarta: Lembaga Kajian \& Advokasi untuk Indenpedensi Peradilan.

Diah Setiawan, S. R. (2016). Tahun 2017, Rasio Pembiayaan Bermasalah Perbankan Syariah di Targetkan Turun jadi 3,45 Persen. Kompas.Com.

Dian, H. F. (2015). Peran Otoritas Jasa Keuangan dalam Perlindungan Hukum Bagi Investor atas Dugaan Investasi Fiktif. Jurnal Law Reform Volume 11, Nomor 2, Tahun 2015.

Firmansyah, I. (2014). Determinant Of Non Performing Loan: The Case Of Islamic Bank In Indonesia. Buletin Ekonomi Moneter dan Perbankan Bank Indonesia, Volume17 No 2.

Florentin, V. (2016). Juli 2016, Kredit Bermasalah Bank Syariah Jadi 4,7 Persen. Tempo.Com.

Hermansyah. (2013). Hukum Perbankan Nasional Indonesia, Ditinjau Menurut Undang-Undang Nomor 7 Tahun 1992 Tentang Perbankan Sebagaimana Telah Diubah Dengan Undang-Undang Nomor 10 Tahun 1998, dan Undang- Undang Nomor 23 Tahun 1999. Jakarta: Kencana Prednada Media Grup.

Iskandar. (2012). Studi Efisiensi Perbankan Syariah di Kota Lhokseumawe dan Aceh Utara. Journal At vol. 12, No. 1 Mei $2012,76$. 
Joni Manurung, d. (2009). Ekonomi Keuangan dan Kebijakan Moneter. Jakarta : Salemba Empat.

Keuangan, O. J. (2014). Booklet Perbankan Indonesia 2014. . Jakarta: Departemen Perizinan \& Informasi Perbankan.

Muhammad. (2002). Managemen Bank Syariah. Yogyakarta: UPP AMP YKPN.

Simorangkir. (2004). Pengantar Lembaga Keungan Bank dan Non Bank. Jakarta: Ghalia Indonesia.

Solahudiin, M. (2004). Resiko Pembiayaan dalam Perbankan Syariah. Benefit, 138. 